Arboriculture \& Urban Forestry 2015. 41(2): 57-68

\title{
A Review of Spatial Variation of Allergenic Tree Pollen Within Cities
}

\author{
Kate R. Weinberger, Patrick L. Kinney, and Gina S. Lovasi
}

\begin{abstract}
Urban trees provide a range of environmental and public health benefits. However, urban trees may also have an adverse effect on human health by increasing exposure to pollen. Many types of tree pollen are considered to be allergens and have been linked to various manifestations of allergic disease, including allergic sensitization, exacerbation of allergic rhinitis, and exacerbation of allergic asthma. An emerging body of literature suggests that the amount of pollen deposited annually varies widely over small spatial scales. While the health impacts of spatial variation in tree pollen within metropolitan areas could be large, the current literature has not been systematically reviewed. To fill this gap in knowledge, this review synthesizes existing evidence on how tree pollen is distributed on an intra-urban spatial scale. A better understanding of the spatial distribution of allergenic tree pollen within urban environments and its relation to health could inform increasingly common urban tree planting programs.

Key Words. Allergic Rhinitis; Allergic Sensitization; Asthma; Pollen; Public Health; Spatial Variability; Urban Trees.
\end{abstract}

Urban areas place large populations of vulnerable people in contact with a range of environmental risks. One strategy to address the health effects of urban pollution, among other ecological and social goals, has involved massive urban tree planting campaigns (Table 1). However, the nascent evidence base linking trees to health has pointed to possible adverse effects as well as health benefits. Recent work has focused on the human health implications of tree canopy coverage (Donovan et al. 2011; Lovasi et al. 2011; Lovasi et al. 2012; Donovan et al. 2013; Lovasi et al. 2013), but has not been able to evaluate the independent or mediating role of local variation in tree pollen exposure.

Exposure to tree pollen is associated with increases in exacerbations of both asthma and allergic rhinitis (Cakmak et al. 2002; Delfino et al. 2002; Villeneuve et al. 2006; Sheffield et al. 2011; Darrow et al. 2012), as well as the risk of developing allergic sensitization to pollen of the same type (Bjorksten et al. 1980; Porsbjerg et al. 2002; Kihlstrom et al. 2003), with a particularly strong association between pollen exposure during infancy and subsequent allergic sensitization (Bjorksten et al. 1980; Kihlstrom et al. 2003). For example, one study found an increased risk of allergic sensitization to birch (Betula spp.) pollen in children at age 4.5 years who were exposed to an unusually high birch pollen season during infancy (Kihlstrom et al. 2003). As major metropolitan areas often have only a single pollen monitoring station, knowledge of these links is primarily based on studies relying on variations in daily tree pollen concentrations measured at a single site. However, an emerging body of literature suggests that the amount of pollen deposited annually at a particular site varies widely over small spatial scales within metropolitan areas. Thus, the implications of urban tree planting efforts for asthma and allergic disease may depend on how the selected species influence the spatial distribution of pollen exposure within cities.

This review synthesizes existing evidence on how tree pollen is distributed on an intra-urban spatial scale. To the best of our knowledge, this is the first systematic review of this topic, although several broader reviews have considered links between local green spaces, trees, or other forms of vegetation and health (Groenewegen et al. 2006; Tzoulas et al. 2007; Bowler et al. 2010; Lee and Maheswaran 2011). Out of the 13 studies that met the inclusion criteria for this review, 12 showed evidence that tree 
pollen varies spatially within cities. These findings were consistent across cities in different geographic regions and across different sampling methodologies. In addition, several studies presented evidence that the distribution of urban trees is a driver of spatial variation in tree pollen within cities.

\section{SEARCH METHODOLOGY}

The study authors developed a search strategy to identify studies that characterize intra-urban spatial variation in tree pollen. The authors conducted a search in PubMed, an electronic citations database of medical literature, using the following search terms:

pollen AND [spatial ${ }^{\star}$ OR spatio ${ }^{\star}$ OR geography ${ }^{\star} \mathrm{OR}$ site OR location ${ }^{*}$ OR neighborhood ${ }^{*}$ OR station $\left.{ }^{*}\right]$

The authors did not restrict the years covered in the search. The authors screened the articles returned by the search first by title, then by abstract, and finally by the full text for inclusion in the review using the following criteria: 1) article is available in English and published online or in print in a peer-reviewed journal on or before February 1, 2014; and 2) tree pollen monitoring was conducted at a minimum of two stationary sites within a single metropoli$\tan$ area. Due to the lack of previous reviews of this topic, the authors did not place limits on the length of pollen sampling, the species considered (e.g., allergenic versus non-allergenic), or the pollen sampling methodology and equipment.

The PubMed search yielded 3,200 articles. Out of these 3,200 articles, the authors excluded 3,072 based on the title, 87 based on the abstract, and 34 based on the full text, leaving seven articles for inclusion in the review. An additional four articles were identified for inclusion from the reference lists of the included articles from the PubMed search, for a total of 11 arti- cles. Finally, as not all studies of spatial variation in tree pollen may be included in the PubMed database, Web of Knowledge, a scientific citations database, was used to identify articles citing these 11 papers. This resulted in the inclusion of an additional two articles, for a final total of 13 .

\section{RESULTS}

\section{Regional Distribution of Studies}

Out of the 13 studies identified for inclusion in this review, eight were conducted in European cities. Celenk et al. (2010) included sampling sites in both the European and the Asian parts of Istanbul, Turkey. Three studies were conducted in the United States, one in Japan, and one in Australia. The time of year at which tree pollen is present (i.e., the tree pollen season) is regiondependent, due in part to differences in climate. In temperate regions, the tree pollen season typically begins in early spring and ends before the beginning of summer (Singh and Mathur 2012). Individual tree pollen taxa tend to be present for a more limited time window within the tree pollen season. For example, in the northeastern United States, the pollen of the cypress family (Cupressaceae) is present in March and April, while oak pollen (Quercus spp.) is present from late April through the end of May (Dvorin et al. 2001). Additionally, the taxa that contribute to the tree pollen season vary from region to region.

Regional variations in the tree pollen season contribute to differences across included studies in terms of the taxa studied and the timing and length of the sampling period, as detailed in Table 2. Most studies sampled pollen for a single tree pollen season or a single year. Studies that monitored pollen for a full year typically did so in order to capture non-arboreal pollen taxa. While the specific taxa examined depend on the region,

Table 1. Selected tree-planting initiatives with unknown effects on health.

\begin{tabular}{lll}
\hline Initiative & Location & Goal \\
\hline MillionTreesNYC & New York City, New York, U.S. & $1,000,000$ trees \\
Million Trees LA & Los Angeles, California, U.S. & $1,000,000$ trees \\
Plant One Million & Pennsylvania, New Jersey, and Delaware, U.S. & $1,000,000$ trees \\
Mile High Million & Denver, Colorado, U.S. & $1,000,000$ trees \\
Green Miami & Miami, Florida, U.S. & $30 \%$ tree canopy \\
Tree Baltimore & Baltimore, Maryland, U.S. & $40 \%$ tree canopy \\
Million Tree Challenge & London, Ontario, Canada & $1,000,000$ trees \\
Shanghai Roots \& Shoots & Shanghai, China & $1,000,000$ trees \\
\hline
\end{tabular}


several genera appear across multiple studies, particularly sycamore (Platanus spp., including the hybrid Platanus $\times$ acerifolia or London planetree), a known allergen (White and Bernstein 2003).

\section{Study Design Characteristics}

Most studies meeting the inclusion criteria used a relatively small number of sampling sites, with three notable exceptions. Ishibashi et al. (2008) used 78 sampling sites during their second year of monitoring; however, the sampling period at these sites was limited to a single 24-hour period in March. Emberlin and Norris-Hill (1991) conducted monitoring for two pollen seasons, using 12 sites in 1987 and 14 sites in 1988. Raynor et al. (1975) constructed a series of sampling lines, each consisting of eight samplers separated by a maximum distance of $486 \mathrm{~m}$ to examine small-scale variation in ragweed pollen (Ambrosia spp.). The remaining studies used between two and four sites within a city.
The height at which sampling was conducted ranged from ground level to $33 \mathrm{~m}$; however, one study did not report the sampling height and two studies reported the number of stories above ground at which sampling occurred but did include the exact height. In addition, seven studies did not conduct pollen monitoring at a uniform height. These height differences make it difficult to interpret whether the detected spatial variability in pollen is truly present, as pollen concentrations have been shown to vary as a function of height up to $15 \mathrm{~m}$. Most pollen types show higher concentrations closer to ground level, although the differences are more pronounced for herbaceous taxa than for arboreal taxa (Rantio-Lehtimaki et al. 1991; Alcazar et al. 1999). Thus, in this review, evidence from the studies in which samplers were placed at uniform height is considered of higher quality. Table 2 provides additional information on the characteristics of the 13 studies.

Table 2. Study characteristics.

\begin{tabular}{|c|c|c|c|c|c|c|}
\hline \multirow{2}{*}{$\begin{array}{l}\text { Study } \\
\text { Celenk et al. } 2010\end{array}$} & \multirow{2}{*}{$\begin{array}{l}\text { Location } \\
\text { Istanbul, Turkey }\end{array}$} & \multirow{2}{*}{$\begin{array}{l}\text { Number of } \\
\text { sampling sites }\end{array}$} & \multirow{2}{*}{$\begin{array}{l}\begin{array}{l}\text { Sampling } \\
\text { period }\end{array} \\
\text { March 1, 2005-February 28, } 2006\end{array}$} & \multirow{2}{*}{$\begin{array}{l}\text { Sampling } \\
\text { height } \\
25 \mathrm{~m}\end{array}$} & \multicolumn{2}{|c|}{$\begin{array}{l}\text { Minimum and maximum sampling } \\
\text { type distance between sites }\end{array}$} \\
\hline & & & & & Not reported & Volumetric \\
\hline Katelaris et al. 2004 & Sydney, Australia & 3 & August-November 1999 & $15 \mathrm{~m}$ & $\begin{array}{l}30 \mathrm{~km} \text { (maximum), } \\
\text { minimum not } \\
\text { reported }\end{array}$ & Volumetric \\
\hline Gonzalo-Garjo et al. 2006 & Badajoz, Spain & 4 & $\begin{array}{l}27 \text { days between March 7, 2003- } \\
\text { February 26, } 2004\end{array}$ & $\begin{array}{l}6 \mathrm{~m} \text { (1 site), ground } \\
\text { level ( } 3 \text { sites) }\end{array}$ & Not reported & Volumetric \\
\hline Alcazar et al. 2004 & Cordoba, Spain & 4 & $\begin{array}{l}26 \text { days between February-April 2000, } \\
12 \text { days between March-April } 2001\end{array}$ & $15 \mathrm{~m}$ & Not reported & Volumetric \\
\hline Myszkowska et al. 2012 & Cracow, Poland & 2 & April-October 2011 & $15 \mathrm{~m}$ (1 site), $20 \mathrm{~m}$ (1 site) & $1.5 \mathrm{~km}$ & Volumetric \\
\hline Nowak et al. 2012 & Poznan, Poland & 2 & $2005-2009$ & $33 \mathrm{~m}$ (1 site), $22 \mathrm{~m}$ (1 site) & $8 \mathrm{~km}$ & Volumetric \\
\hline Rodriguez-Rajo et al. 2010 & Poznan, Poland & 2 & $2005-2007$ & $33 \mathrm{~m}$ (1 site), $22 \mathrm{~m}$ (1 site) & $8 \mathrm{~km}$ & Volumetric \\
\hline Velasco-Jiménez et al. 2012 & Cordoba, Spain & 2 & $2006-2010$ & $15 \mathrm{~m}$ (1 site), $22 \mathrm{~m}$ (1 site) & Not reported & Volumetric \\
\hline Raynor et al. 1975 & $\begin{array}{l}\text { Multiple cities in } \\
\text { New York, U.S. }\end{array}$ & $\begin{array}{l}3 \text { sampling lines } \\
\text { (one per city) } \\
\text { with } 8 \text { samplers } \\
\text { per line }\end{array}$ & $\begin{array}{l}\text { 5-20 minute samples, } \\
1971-1972\end{array}$ & $1.5 \mathrm{~m}$ & $\begin{array}{l}1 \mathrm{~m} \text { (minimum), } \\
486 \mathrm{~m} \text { (maximum) }\end{array}$ & Impactor \\
\hline White et al. 2005 & $\begin{array}{l}\text { Cincinnati, Ohio, } \\
\text { U.S. }\end{array}$ & 2 & 2002 & $\begin{array}{l}12.2 \mathrm{~m} \text { ( } 1 \text { site), } \\
\text { ground level (1 site) }\end{array}$ & $16 \mathrm{~km}$ & Impactor \\
\hline Frenz et al. 1997 & $\begin{array}{l}\text { St. Paul, Minnesota, } \\
\text { U.S. }\end{array}$ & 2 & April-October 1993 & $\begin{array}{l}2 \text {-story building ( } 1 \text { site), } \\
1 \text {-story building ( } 1 \text { site) }\end{array}$ & $5.6 \mathrm{~km}$ & Impactor \\
\hline $\begin{array}{l}\text { Emberlin and Norris-Hill } \\
1991\end{array}$ & North London, UK & $\begin{array}{l}12(1987) \\
14(1988)\end{array}$ & $1987-1988$ & 6-story buildings & Not reported & Gravimetric \\
\hline Ishibashi et al. 2008 & Tokyo, Japan & $\begin{array}{l}32(2005) \\
78(2006)\end{array}$ & $\begin{array}{l}\text { March 15-16, 2005, } \\
\text { March 14-15, } 2006\end{array}$ & Not reported & Not reported & Gravimetric \\
\hline
\end{tabular}




\section{Sampling Methodologies}

Several types of samplers are available to sample the pollen content of the atmosphere. The choice of sampler(s) employed by a study is important as it affects the time scale and unit of the measurements. Eight studies conducted pollen monitoring using Hirst-type volumetric samplers (Hirst 1952). Volumetric samplers, which are typically used to take 24-hour samples of atmospheric pollen, draw in air at a constant flow rate and allow pollen to impact on a piece of tape secured on a rotating drum. Knowledge of the flow rate allows the calculation of the actual pollen concentration in grains $/ \mathrm{m}^{3}$.

Three studies used impactor samplers, such as the Rotorod (Multidata LLC, St. Louis Park, Minnesota, U.S.). Impactors consist of a set of greased rods or slides attached to a head that rotates such that pollen is impacted on the greased surfaces. As with Hirst-type samplers, impactors allow the calculation of a concentration in grains $/ \mathrm{m}^{3}$. These samplers tend to be less efficient than Hirst-type samplers at retrieving very small pollen grains (less than $10 \mu \mathrm{m}$ in diameter) (Solomon et al. 1980).

The two remaining studies employed gravimetric samplers. These samplers, such as the designs of Tauber (Tauber 1974) and Durham (Durham 1946), depend on gravity to passively sample the pollen content of the atmosphere and are cheaper and simpler than volumetric and impactor samplers. Because the sampling method is passive, pollen counts are reported as influx (i.e., deposition) in grains $/ \mathrm{cm}^{2}$ rather than as a concentration. Crispen et al. (2010) have shown that Durham traps, which were used in the two gravimetric studies included in this review, are comparable to Burkard traps when examining the relative frequencies with which pollen taxa appear (Crispen et al. 2010). Durham traps can be left out for varying periods of time, but are typically replaced daily (Singh and Mathur 2012).

While all three sampling types allow pollen to be measured on a daily basis (as a concentration for volumetric and impactor samplers, and as influx for gravimetric samplers), most of the included studies examined the total amount of pollen sampled in a given year by summing the daily values across an entire pollen season or year and comparing this total value across sites. These values are still reported as a concentration or as influx, and are often referred to as the "severity" or "mag- nitude" of the pollen season. Some studies report this value only for the aggregate of all tree pollen taxa, while others report taxon-specific values.

With the exception of one study employing only two sampling sites (White et al. 2005), all the studies revealed spatial differences in atmospheric tree pollen concentrations or influx within urban areas regardless of sampler type. The following literature review will group the 13 studies by sampling methodology and discuss their major findings in detail. A summary of findings is also presented in Appendix I.

\section{Evidence from Volumetric Samplers}

Out of the eight studies using volumetric samplers, the most compelling evidence comes from the four studies in which pollen was measured at a uniform height. Celenk et al. (2010) monitored pollen for a full calendar year at two sites, each $25 \mathrm{~m}$ high, in Istanbul, Turkey, one on the European continent and one on the Asian continent. Over the course of a year, the total number of tree pollen grains was more than 35\% higher at the European site than at the Asian site (28,227 grains versus 20,894 grains). When the authors examined total annual catches of individual pollen taxa, some were similar between the two sites while others showed large differences. Not all pollen types were more common at the Asian site. For example, total sycamore pollen was six times higher at the European site than the Asian site.

Katelaris et al. (2004) measured pollen at three sites in Sydney, Australia, from August to November (Southern Hemisphere spring) of 1999. The total pollen concentrations summed across the whole sampling period were 14,382 grains $/ \mathrm{m}^{3}, 11,584$ grains $/ \mathrm{m}^{3}$, and 9,269 grains $/ \mathrm{m}^{3}$ at the three sites (Homebush, Eastern Creek, and Nepean, respectively). Thus, the total pollen concentration was approximately 55\% higher at Homebush than at Nepean. The authors examined differences in daily pollen concentrations by classifying daily concentrations of total pollen into high, medium, and low concentrations and evaluating pairs of sites for discordance in the classification of each day. On $8 \%$, $13 \%$, and $17 \%$ of days, pollen concentrations were discordant at Eastern Creek versus Nepean, Homebush versus Nepean, and Homebush versus Eastern Creek, respectively, indicating that spatial variability in pollen exists on a daily as well as on a seasonal timescale. The authors did not examine any pollen 
taxa individually, so it is not clear if certain pollen taxa contribute to this discordance more than others.

Gonzalo-Garjo et al. (2006) examined pollen concentrations at four sites in Badajoz, Spain, for a total of 27 days at intervals from March 7, 2003, to February 26, 2004. Sampling was carried out at six meters above ground at one suburban site and at ground level at three urban sites. Four major tree taxa were identified from the samplers: oak, olive (Olea spp.), the cypress family, and sycamore. No differences between any of the four traps were detected for the cypress family. For oak, the urban traps were not significantly different from each other, but they were significantly different from the suburban trap. The change in sampling height limit one's ability to interpret whether differences in pollen concentrations between the urban and suburban traps were truly due to spatial variability, although the three urban sites themselves are comparable. For olive and sycamore, the urban traps were significantly different not only from the suburban trap but also from each other.

Alcazar et al. (2004) examined sycamore concentrations at four sites in Cordoba, Spain (northern, southern, center, and western) for 26 days at intervals between February and April of 2000, and for 12 days at intervals between March and April of 2001. Samples at the western site were collected with a Hirst-type volumetric spore trap, while samples at the other three sites were collected with portable Lanzoni VPPS samplers. The Hirst-type trap has a wind vane so that the intake is always facing into the wind, while the three Lanzoni samplers did not have this feature, limiting the comparability of the western site to the others. However, there were differences in the total amount of sycamore pollen collected over the sampling periods among the three sites that used the Lanzoni samplers. The total concentration ranged from 241 grains $/ \mathrm{m}^{3}$ at the northern site to 48,957 grains $/ \mathrm{m}^{3}$ at the southern site in 2000 (a greater than 200 -fold difference), and from 664 grains $/ \mathrm{m}^{3}$ at the northern site to 16,335 grains $/ \mathrm{m}^{3}$ at the center site in 2001 (a greater than 20-fold difference). The authors report that sycamore trees are less common in the northern part of the city, suggesting an influence of local vegetation.

The four remaining studies employing volumetric samplers also revealed spatial variation in tree pollen distribution but the evidence is less compelling. These studies all used two sites each, and in each case the sites were not at the same height. Myszkowska et al. (2012) measured pollen concentrations at two sites in Cracow, Poland, between April and October of 2011. These sites were separated by only $1.5 \mathrm{~km}$, one of the shortest reported separation distances among the studies included in this review. The total amount of tree pollen collected over the season was about $7 \%$ higher at site $\mathrm{L}$ than at site B $\left(12,414\right.$ grains $/ \mathrm{m}^{3}$ versus 11,631 grains $/ \mathrm{m}^{3}$ ). More pronounced differences in total pollen collected over the season were observed for some tree taxa, including several known allergens. For example, total birch pollen was $34 \%$ higher at site $\mathrm{B}$ than at site $\mathrm{L}\left(2,130\right.$ grains $/ \mathrm{m}^{3}$ versus 1,584 grains $/ \mathrm{m}^{3}$ ), and maple (Acer spp.) was almost 16 times higher at site L than at site B (207 grains/ $\mathrm{m}^{3}$ versus 13 grains $/ \mathrm{m}^{3}$ ). However, two issues limit our ability to infer spatial variation in pollen in this study. First, different samplers were used at the two sites: a Lanzoni VPPS 2000 at site $\mathrm{L}$ and a Burkard volumetric spore trap at site B. Second, the Lanzoni trap was located $15 \mathrm{~m}$ high, while the Burkard trap was located $20 \mathrm{~m}$ high.

Nowak et al. (2012) measured sycamore pollen at two sites at heights of 22 and $33 \mathrm{~m}$ in Poznan, Poland, from 2005 to 2009. Differences in annual total sycamore concentrations ranged from 10- to 20-fold. Rodriguez-Rajo et al. (2010) report pollen measurements for six taxa (three tree taxa and three herbaceous taxa) from the same two sites as Nowak et al. (2012), but from a more limited set of years (2005-2007). The authors found that the total amount of each pollen type collected over the three-year period, as well as the number of days with pollen concentrations higher than 50 grains/ $\mathrm{m}^{3}$, was higher at the $22 \mathrm{~m}$ high site than at the 33 $\mathrm{m}$ high site, although the differences were larger for the herbaceous taxa than the tree pollen taxa.

Finally, Velasco-Jiménez et al. (2012) examined pollen concentrations at two sites in Cordoba, Spain, from 2006 to 2010. One trap was located in the southwest of the city at $15 \mathrm{~m}$, and the other was located in the northwest at $22 \mathrm{~m}$. The authors looked at differences in the daily (rather that annual total) pollen concentrations and found that daily concentrations of most pollen taxa were not significantly different at the two sites, with some 
exceptions. Olive, sycamore, and the nettle family (Urticaceae) were higher in the southwest, while oak, cypress (Cupressus spp.), and poplar (Populus spp.) were higher in the northeast in most years.

\section{Evidence from Impactor Samplers}

Raynor et al. (1975) constructed sampling lines consisting of eight samplers each separated by a minimum distance of $1 \mathrm{~m}$ and a maximum distance of $486 \mathrm{~m}$ in various locations in New York state. The authors looked at total tree pollen as well as ragweed pollen. Differences between pairs of samplers in a given sampling line increased as a function of distance in most tests. Even samples taken only $1 \mathrm{~m}$ apart had an average $18 \%$ difference. Samples taken at the maximum distance from each other $(486 \mathrm{~m})$ had an average $25 \%$ difference. These relationships were similar across sampling locations and pollen types. The authors concluded that pollen near groundlevel may not be well mixed, even in the absence of local sources, while noting that differences in the collection efficiency of the Rotoslide samplers could have contributed to the results seen.

The remaining two studies provide less compelling evidence, again due to differences in sampling height. As part of a study on allergic sensitization to pollen, White et al. (2005) measured pollen at two sites in Cincinnati, Ohio, U.S. One site was in an urban area at $12.2 \mathrm{~m}$ high, while the other was a suburban site at ground level. In a paired t-test, daily total pollen concentrations were not significantly different between the sites $(P=0.24)$. No information on individual taxa was presented. Information on the annual total of tree pollen at each site was not presented.

Frenz et al. (1997) report the results of monitoring conducted at two sites $5.6 \mathrm{~km}$ apart in St. Paul, Minnesota, U.S. One site was located on a one-story building (Snelling) while the other was located on a two-story building (Wycliff). Total pollen over the sampling period was similar at the two sites (17,188 grains at Wycliff versus 17,341 grains at Snelling). However, differences appeared when results were examined by month, with higher counts at the Snelling site in April and May, and higher counts at the Wycliff site in June through October. The authors suggested that local vegetation plays a role, as the Snelling site is close to streets lined with trees that release pollen in the spring, while the Wycliff site was an industrial environment more conducive to grass and weed growth.

\section{Evidence from Gravimetric Samplers}

The two studies that included the largest number of sampling sites both used gravimetric sampling methods. Emberlin and Norris-Hill (1991) sampled several pollen taxa at 12 sites in 1987 and at 14 sites in 1988 in North London, UK. They found substantial variation in annual pollen influx across the sites. The largest difference between any two sites was $646 \%$ for sycamore pollen. The authors suggest that the presence of a great number of sycamore trees within the city contributed to the magnitude of the variability.

Ishibashi et al. (2008) measured pollen in Tokyo, Japan, at 32 sites for one 24-hour period in March 2005 and at 78 sites for one 24-hour period in March 2006. Total pollen influx was approximately 10 times higher in 2005 than in 2006. However, in both years, influx was higher in suburban and rural locations than in the urban city center. No statistical testing was performed relating land-use characteristics to pollen counts, nor were any taxa-specific results presented.

\section{Effect of Local Vegetation}

Several studies presented evidence that local vegetation was a driver of spatial variation in tree pollen. For example, Gonzalo-Garjo et al. (2006) used information from a tree census in the study area and found that the site with the highest sycamore pollen concentration was closer to major stands of sycamore trees than the two sites with lower concentrations, although the exact distances and densities of the stands were not reported. Katelaris et al. (2004) conducted vegetation surveys in 2,000 $\mathrm{m}$ circular buffers of their three sampling sites and found differences in local vegetation that paralleled differences in total pollen concentrations. However, no taxa-specific information was reported. In the study by Nowak et al. (2012), one site was located $100 \mathrm{~m}$ from the closest sycamore trees, while the other was 6.5 $\mathrm{km}$ from the closest sycamore trees. Annual sycamore totals were 10 to 20 times lower at the site that was farthest from the sycamore trees, suggesting that most sycamore pollen does not travel 
far from its source and that local sources are important drivers of local pollen concentrations. Other studies mentioned that local vegetation may help explain their results but did not include systematic investigations such as tree surveys.

\section{DISCUSSION}

Out of the 13 studies that met the inclusion criteria for this review, 12 found evidence that the amount of tree pollen measured over the sampling period (or in each year in the case of studies that monitored for multiple years) was different at sites within a single city. In some cases, the magnitude of the variability was quite large. For example, Alcazar et al. (2004) found that the total annual sycamore concentration varied by a factor of 200 between two sites. White et al. (2005) did not find statistically significant differences in daily total pollen concentrations at two sites in Cincinnati, Ohio, but did not examine the annual total, nor did they look at whether there were differences by pollen type.

Study designs varied widely. The magnitude of the variability observed is not comparable across cities due to differences in sampler height, taxa examined, and the distance between and characteristics of the sites. Some studies only reported results for the aggregate of all pollen taxa (or in some cases, all arboreal pollen taxa), while others reported results for individual pollen families or genera. The latter group of studies found the magnitude of variation is taxon-specific. Sycamore, the most commonly investigated individual genus, was consistently found to vary substantially on an intraurban scale. While the primary focus of this report is spatial variation in tree pollen, it is worth noting that non-arboreal pollen taxa may vary within urban areas as well. For example, Emberlin and Norris-Hill (1991) also examined differences in grass pollen (Poaceae) across sites in North London and found that the largest percent difference between any two sampling sites was 77\%. Raynor et al. (1975) found differences in ragweed pollen concentrations at a very small spatial scale $(1 \mathrm{~m})$. Studies that did not meet the criteria for this review because they did not measure tree pollen also reveal spatial differences in grass and ragweed pollen (Puc and Puc 2004). For example, Barnes et al. (2001) monitored ragweed pollen using volumetric samplers at four sites in Kansas City, Missouri, U.S., and found that daily ragweed concentrations tended to be higher in suburban sites than in an urban site.

The most common study limitation was differences in sampling heights. This was an issue in six studies (Frenz et al. 1997; White et al. 2005; Rodriguez-Rajo et al. 2010; Myszkowska et al. 2012; Nowak et al. 2012; Velasco-Jiménez et al. 2012), including the study from White et al. (2005), which revealed no differences in daily pollen measured at two sites. In addition, the length of sampling varied widely between studies. Ishibashi et al. (2008) used the largest number of sampling sites (78 sites in 2006), but these samplers were only deployed for a single 24-hour period. It is impossible to say whether the patterns revealed during those 24 hours would have been stable over the course of an entire year.

If tree pollen does indeed vary spatially within cities, an important next question is whether patterns in tree pollen are stable across years. Five studies measured pollen for more than one year; however, three of these conducted pollen monitoring at different heights. Ishibashi et al. (2008) found that pollen levels were higher in suburban and rural areas than in urban areas in two years, but the sampling period was limited to a single 24-hour period in each year. Alcazar et al. (2004) monitored sycamore at uniform height, and found that the northern site had the lowest totals in both years of monitoring. However, the southern site had the highest total in 2000, while the central site had the highest total in 2001. Nowak et al. (2012) found that total sycamore concentrations were between 10 and 20 times lower at a site that was far from the closest sycamore trees than at a site that was close to a stand of sycamore for all years 2005 to 2009, but the two samplers were placed at different heights. Clearly, more information is needed in order to draw conclusions regarding the stability of spatial patterns over multiple years.

\section{RECOMMENDATIONS FOR FUTURE RESEARCH}

Taken together, the results of all 13 studies provide evidence that there is spatial variation in the distribution of tree pollen within cities. However, additional research is needed to characterize the stability of patterns of pollen distribution across years as well as the extent to which local vegetation and other land-use characteristics affect local pollen levels. Multi-year pollen monitoring, in 
which pollen taxa are reported individually, could be combined with tree surveys to help answer these questions. Such studies would benefit from a larger number of monitoring sites than has been typically used in the past. This would allow for formal statistical testing of the relationship between tree density and local pollen levels. In addition, multiyear pollen monitoring in cities undergoing large urban tree planting campaigns could shed light on whether such campaigns change spatial patterns of tree pollen. Finally, spatial pollen measurements could be linked to epidemiologic studies to investigate whether local pollen exposure influences the development or exacerbation of allergic disease.

Acknowledgments. We would like to thank the two anonymous reviewers for their feedback. This review was funded by the International Society of Arboriculture as part of its literature review series.

\section{LITERATURE CITED}

Alcazar, P., P. Carinanos, C. De Castro, F. Guerra, C. Moreno, E Dominguez-Vilches, and C. Galan. 2004. Airborne plane-tree (Platanus hispanica) pollen distribution in the city of Cordoba, southwestern Spain, and possible implications on pollen allergy. Journal of Investigational Allergology and Clinical Immunology 14(3):238-43.

Alcazar, P., C. Galan, P. Carinanos, and E. Domínguez-Vilches. 1999. Effects of sampling height and climatic conditions in aerobiological studies. Journal of Investigational Allergology and Clinical Immunology 9(4):253-261.

Barnes, C., F. Pacheco, J. Landuyt, F. Hu, and J. Portnoy. 2001. Hourly variation of airborne ragweed pollen in Kansas City. Annals of Allergy, Asthma \& Immunology 86(2):166-71.

Bjorksten, F., I. Suoniemi, and V. Koski. 1980. Neonatal birch-pollen contact and subsequent allergy to birch pollen. Clinical and Experimental Allergy 10(5):585-591.

Bowler, D.E., L.M. Buyung-Ali, T.M. Knight, and A.S. Pullin. 2010. A systematic review of evidence for the added benefits to health of exposure to natural environments. BMC Public Health 10(1):456.

Cakmak, S., R.E. Dales, R.T. Burnett, S. Judek, F. Coates, and J.R. Brook. 2002. Effect of airborne allergens on emergency visits by children for conjunctivitis and rhinitis. Lancet 359(9310):947-948.

Celenk, S., A. Bicakci, Z. Tamay, N. Guler, M.K. Altunoglu, Y. Canitez, H. Malyer, N. Sapan, and U. Ones. 2010. Airborne pollen in European and Asian parts of Istanbul. Environmental Monitoring and Assessment 164(1-4):391-402.

Crispen, K.L., D.N. Gillespie, E.C. Weiler, C.W. Noonan, R.F. Hamilton, and T.J. Ward. 2010. A comparison of 1978 and 2006 peak pollen seasons and sampling methods in Missoula, Montana. Grana 49(2):128-133.

Darrow, L.A., J. Hess, C.A. Rogers, P.E. Tobert, M. Klein, and S.E. Sarnat. 2012. Ambient pollen concentrations and emergency department visits for asthma and wheeze. Journal of Allergy and Clinical Immunology 130(3):630-638.

Delfino, R.J., R.S. Zeiger, J.M. Seltzer, D.H. Street, and C.E. McLaren. 2002. Association of asthma symptoms with peak particulate air pollution and effect modification by antiinflammatory medication use. Environmental Health Perspectives 110(10):A607-A617.

Donovan, G.H., D.T. Butry, Y.L. Michael, J.P. Prestemon, A.M. Liebhold, D. Gatziolis, and M.Y. Mao. 2013. The relationship between trees and human health: Evidence from the spread of the emerald ash borer. American Journal of Preventive Medicine 44:139-145.

Donovan, G.H., Y.L. Michael, D.T. Butry, A.D. Sullivan, and J.M. Chase. 2011. Urban trees and the risk of poor birth outcomes. Health \& Place 17:390-393.

Durham, O.C. 1946. The volumetric incidence of atmospheric allergens: A proposed standard method of gravity sampling, counting, and volumetric interpolation of results. Journal of Allergy 17:79-86.

Dvorin, D.J., J.J. Lee, G.A. Belecanech, M.F. Goldstein, and E.H. Dunsky. 2001. A comparative, volumetric survey of airborne pollen in Philadelphia, Pennsylvania (1991-1997) and Cherry Hill, New Jersey (1995-1997). Annals of Allergy, Asthma \& Immunology 87(5):394-404.

Emberlin, J., and J. Norris-Hill. 1991. Spatial variation of pollen deposition in North London. Grana 30:190-195.

Frenz, D.A., S.E. Melcher, L.W. Murray, and R.E. Sand. 1997. A comparison of total pollen counts obtained $5.6 \mathrm{~km}$ apart. Aerobiologia 13:205-208.

Gonzalo-Garjo, M.A., R. Tormo-Molina, A.F. Munoz-Rodriguez, and I. Silva-Palacios. 2006. Differences in the spatial distribution of airborne pollen concentrations at different urban locations within a city. Journal of Investigational Allergology and Clinical Immunology 16(1):37-43.

Groenewegen, P.P., A.E. van den Berg, S. de Vries, and R.A. Verheij. 2006. Vitamin G: Effects of greenspace on health, well-being, and social safety. BMC Public Health 6(149).

Hirst, J. 1952. An automatic volumetric spore trap. Annals of Applied Biology 39:257-265.

Ishibashi, Y., H. Ohno, S. Oh-ishi, T. Matsuoka, T. Kizaki, and K. Yoshizumi. 2008. Characterization of pollen dispersion in the neighborhood of Tokyo, Japan in the spring of 2005 and 2006. International Journal of Environmental Research and Public Health 5(1):76-85.

Katelaris, C.H., T.V. Burke, and K. Byth. 2004. Spatial variability in the pollen count in Sydney, Australia: Can one sampling site accurately reflect the pollen count for a region? Annals of Allergy, Asthma \& Immunology 93(2):131-136.

Kihlstrom, A., G. Lilja, G. Pershagen, and G. Hedlin. 2003. Exposure to high doses of birch pollen during pregnancy and risk of sensitization and atopic disease in the child. Allergy 58(9):871-877.

Lee, A.C., and R. Maheswaran. 2011. The health benefits of urban green spaces: A review of the evidence. Journal of Public Health 32(2):212-222.

Lovasi, G.S., M.D. Bader, J. Quinn, K. Neckerman, C. Weiss, and A. Rundel. 2012. Body mass index, safety hazards, and neighborhood attractiveness. American Journal of Preventive Medicine 43:378-384.

Lovasi, G.S., J.S. Jacobson, J.W. Quinn, K.M. Neckerman, M.N. Ashby-Thompson, and A. Rundle. 2011. Is the environment near home and school associated with physical activity and adiposity of urban preschool children? Journal of Urban Health 88:1143-1157. 
Lovasi, G.S., O. Schwartz-Soicher, J.W. Quinn, D.K. Berger, K. Neckerman, R. Jaslow, K.K. Lee, and A. Rundle. 2013. Neighborhood safety and green space as predictors of obesity among preschool children from low-income families in New York City. Preventive Medicine 57(3):189-193.

Myszkowska, D., D. Stepalska, W. Dyga, J. Bokalska-Rajba, and E. Czarnobilska. 2012. Survey of biological particles in the atmosphere of the Cracow center (southern Poland) in 2011. Preliminary study. Przegląd Lekarski 69(12):1254-1260.

Nowak, M., A. Szymanska, and L. Grewling,. 2012. Allergic risk zones of plane tree pollen (Platanus sp.) in Poznan. Postepy Dermatologii I Alergologii 29(3):156-160.

Porsbjerg, C., M.L. Linstow, S.C.Nepper-Christensen, A. Rasmussen, J. Korsgaard, H. Nolte, and V. Backer. 2002. Allergen sensitization and allergen exposure in Greenlander Inuit residing in Denmark and Greenland. Respiratory Medicine 96(9):736-744.

Puc, M., and M.I. Puc. 2004. Allergenic airborne grass pollen in Szczecin, Poland. Annals of Agricultural and Environmental Medicine 11(2):237-244.

Rantio-Lehtimaki, A., A. Koivikko, R. Kupias, Y. Makinen, and A. Pohjola. 1991. Significance of sampling height of airborne particles for aerobiological information. Allergy 46(1):68-76.

Raynor, G.S., E.C. Ogden, and J.V. Hayes. 1975. Spatial variability in airborne pollen concentrations. Journal of Allergy and Clinical Immunology 55(3):195-202.

Rodriguez-Rajo, F.J., D. Fdez-Sevilla, A. Stach, and V. Jato. 2010. Assessment between pollen seasons in areas with different urbanization level related to local vegetation sources and differences in allergen exposure. Aerobiologia 26(1):1-14.

Sheffield, P.E., K.R. Weinberger, K. Ito, T.D. Matte, R.W. Mathes, G.S. Robinson, and P.L. Kinney. 2011. The association of tree pollen concentration peaks and allergy medication sales in New York City: 2003-2008. ISRN Allergy.

Singh, A.B., and C. Mathur. 2012. An aerobiological perspective in allergy and asthma. Asia Pacific Allergy 2(3):210-222.

Solomon, W.R., H.A. Burge, J.R. Boise, and M. Becker. 1980. Comparative particle recoveries by the retracting rotorod, rotoslide and burkard spore trap sampling in a compact array. International Journal of Biometeorology 24(2):107-116.

Tauber, H. 1974. A static non-overload pollen collector. New Phytologist 73:359-369.

Tzoulas, K., K. Korpela, S. Venn, V. Yli-Pelkonen, A. Kazmierczak, J. Niemela, and P. James. 2007. Promoting ecosystem and human health in urban areas using green infrastructure: A literature review. Landscae and Urban Planning 81(3):167-178.

Velasco-Jiménez, M.J., P. Alcazar, E. Domínguez-Viches, and C. Galán. 2012. Comparative study of airborne pollen counts located in different areas of the city of Córdoba (southwestern Spain). Aerobiologia 29(1):113-120.

Villeneuve, P.J., M.S. Doiron, D. Stieb, R. Dales, R.T. Burnett, and R. Dugandzic. 2006. Is outdoor air pollution associated with physician visits for allergic rhinitis among the elderly in Toronto, Canada? Allergy 61(6):750-758.

White, J.F., and D.I. Bernstein. 2003. Key pollen allergens in North America. Annals of Allergy, Asthma \& Immunology 91(5):425-435.

White, J.F., L. Levin, M. Villareal, K. Murphy, R. Biagini, L. Wellinghoff, H.G. St. Clair, and D.I. Bernstein. 2005. Lack of correlation between regional pollen counts and percutaneous reactivity to tree pollen extracts in patients with seasonal allergic rhinitis. Annals of Allergy, Asthma \& Immunology 94(2):240-246.
Kate R. Weinberger, M.A. (corresponding author) Department of Environmental Health Sciences Mailman School of Public Health Columbia University

722 West 168th Street, 11th Floor

New York City, New York 10032, U.S.

krw2114@cumc.columbia.edu

Patrick L. Kinney, Sc.D.

Department of Environmental Health Sciences

Mailman School of Public Health

Columbia University

722 West 168th Street, Room 1104E

New York City, New York 10032, U.S.

Gina S. Lovasi, Ph.D., M.P.H.

Department of Epidemiology

Mailman School of Public Health

Columbia University

722 W 168th St, Room 804

New York City, New York 10032, U.S. 


\section{APPENDIX I. MAJOR FINDINGS BY STUDY.}

\begin{tabular}{ll} 
Study & Taxa \\
\hline Celenk et al. 2010 & All
\end{tabular}

Katelaris et al. 2004

All

Gonzalo-Garjo

et al. 2006

Alcazar et al. 2004

Myszkowska

et al. 2012

Nowak et al. 2012

Rodriguez-Rajo

et al. 2010

Velasco-Jiménez

et al. 2012

Raynor et al. 1975

All

All
Taxa

Major findings

Over the course of the year, the total number of tree pollen grains was more than 35\% higher at the European site than at the Asian site (28,227 grains versus 20,894 grains).

Total pollen concentrations for the entire sampling period were 14,382 grains $/ \mathrm{m}^{3}, 11,584$ grains $/ \mathrm{m}^{3}$, and 9,269 grains $/ \mathrm{m}^{3}$ at the three sites (Homebush, Eastern Creek, and Nepean, respectively). Daily concentrations of total pollen were classified into high, medium, and low concentrations. Pairs of sites were evaluated for discordance in the classification of days. On $8 \%, 13 \%$, and $17 \%$ of days, pollen concentrations were high at one site and low at the other for Eastern Creek versus Nepean, Homebush versus Nepean, and Homebush versus Eastern Creek, respectively.

No differences between any of the four traps were detected for the cypress family. For oak, the urban traps were not significantly different from each other, but they were significantly different from the suburban trap. For olive and sycamore, the urban traps were significantly different not only from the suburban trap but also from each other.

Sycamore

Sycamore

Birch, hazelnut, alder, and three herbaceous taxa

Total tree pollen, Differences between pairs of samplers in a giving sampling line ragweed
Daily concentrations of most pollen types were not significantly different at the two sites, with some exceptions. Olive, sycamore, and the nettle family were higher at the southwest site, while oak, cypress, and poplar were higher at the northeast site in most years.

The total concentration ranged from 241 grains $/ \mathrm{m}^{3}$ at the northern site to 48,957 grains $/ \mathrm{m}^{3}$ at the southern site in 2000 (a greater than 200fold difference), and from 664 grains $/ \mathrm{m}^{3}$ at the northern site to 16,335 grains $/ \mathrm{m}^{3}$ at the center site in 2001 (a greater than 20-fold difference).

The total amount of tree pollen collected over the season was about $7 \%$ higher at site $\mathrm{L}$ than at site $\mathrm{B}\left(12,414\right.$ grains $/ \mathrm{m}^{3}$ versus 11,631 grains $/ \mathrm{m}^{3}$ ). More pronounced differences in total pollen collected over the season were observed for some tree taxa.

Annual sycamore totals were 10 to 20 times lower at the site farther from sycamore trees than at a site closer to sycamore trees.

The total amount of each pollen type collected over the three-year period, as well as the number of days with pollen concentrations higher than 50 grains $/ \mathrm{m}^{3}$, was higher at a rural site than at a urban site. The differences were larger for the herbaceous taxa than the tree pollen taxa.

increased as a function of distance in most tests. Even samples taken 
White et al. 2005

Frenz et al. 1997

Emberlin and

Norris-Hill 1991

Ishibashi et al. 2008
All

All

only $1 \mathrm{~m}$ apart had an average $18 \%$ difference. Samples taken at the maximum distance from each other $(486 \mathrm{~m})$ had an average $25 \%$ difference.

Using a paired t-test, daily total pollen concentrations were not significantly different between the sites $(P=0.24)$.

Total pollen over the sampling period was similar at the two sites $(17,188$ grains at Wycliff versus 17,341 grains at Snelling). However, differences appeared when results were examined by month, with higher counts at the Snelling site in April and May and higher counts at the Wycliff site in June through October.

Birch, sycamore, Substantial variation in annual pollen influx was seen across the sites, grass with the largest difference between sites $646 \%$ for sycamore.

Total pollen concentrations were approximately 10 times higher in 2005 than in 2006. In both years, pollen counts were higher in suburban and rural locations than in the urban city center. 
Résumé. Les arbres urbains fournissent un éventail de bénéfices environnementaux et d'impacts favorables sur la santé publique. Cependant, les arbres urbains peuvent également avoir un effet contraire sur la santé humaine en augmentant l'exposition au pollen. De nombreux types de pollen d'arbres sont considérés comme allergènes et ont été associés à diverses réactions allergènes, incluant la sensibilisation allergique, l'exacerbation de la rhinite allergique saisonnière et l'exacerbation de l'asthme d'origine allergique. Une importante bibliographie récente suggère que la quantité de pollen déposée chaque année en milieu urbain varie considérablement en fonction de l'échelle des petits espaces. Bien que les impacts sur la santé de la variation spatiale du taux de pollen dans les zones métropolitaines puissent être importants, aucune revue de littérature contemporaine n'a pourtant été effectuée de manière systématique. Afin de combler ladite lacune sur le plan des connaissances, cette revue de littérature synthétise les données existantes sur la manière dont le pollen des arbres est propagé à l'échelle d'espaces intra-urbains. Une meilleure compréhension de la distribution spatiale du pollen d'arbre allergène dans les milieux urbains et sa relation avec la santé publique pourraient influencer de manière significative les programmes annuels de plantation d'arbres.

Zusammenfassung. Straßenbäume bieten eine Reihe von ökologischen Vorteilen für die Umwelt und die Anwohner. Dennoch können Straßenbäume auch einen gegenteiligen Einfluss auf die Gesundheit haben indem sie vermehrt Pollen produzieren. Viele Typen von Gehölzpollen werden als allergen betrachtet und sind mit verschiedenen Manifestationen von allergischen Krankheiten, einschließlich allergischer Sensitization, Exazerbationen von allergischer Rhinitis und Exazerbation von allergischem Asthma verbunden. Ein wachsender Teil an Literatur sagt aus, dass die Menge von jährlich deponiertem Pollen in kleinen räumlichen Skalen weit variiert. Während die Auswirkungen auf die Gesundheit von räumlicher Variation der verschiedenen Baumpollen in Metropolen groß sein könnten, so wurde doch die gegenwärtige Literatur noch nicht systematisch betrachtet. Um diese Wissenslücke zu füllen, untersucht diese Übersicht die vorhandenen Beweise, wie Baumpollen auf einer intra-urbanen räumlichen Skala verteilt werden. Ein besseres Verständnis der räumlichen Verteilung von allergenen Baumpollen im urbanen Umfeld und der Relationen zur Gesundheit könnte die öffentlichen Baumpflanzprogramme zunehmend mit Informationen versorgen.

Resumen. Los árboles urbanos proporcionan una serie de beneficios ambientales y de salud pública. Sin embargo, los árboles urbanos también pueden tener un efecto adverso sobre la salud humana mediante el aumento de la exposición al polen. Muchos tipos de polen de los árboles se consideran alergénicos y se han relacionado con diversas manifestaciones de la enfermedad alérgica, incluyendo sensibilización, rinitis y exacerbación de asma. La literatura sugiere que la cantidad de polen depositado anualmente varía ampliamente en escalas espaciales pequeñas. Mientras que la variación espacial de los impactos del polen de los árboles en la salud dentro de las áreas metropolitanas podría ser grande, la literatura actual no lo ha revisado sistemáticamente. Para llenar este vacío en el conocimiento, esta revisión sintetiza la evidencia existente sobre cómo el polen de los árboles se distribuye en una escala espacial intra-urbana. Una mejor comprensión de la distribución espacial de polen alergénico del árbol dentro de entornos urbanos y su relación con la salud podría informar a los programas comunes de plantación de árboles urbanos. 